\title{
PENGARUH RASIO KEUANGAN TERHADAP HARGA SAHAM PADA PERUSAHAAN ROKOK YANG TERDAFTAR DI BURSA EFEK INDONESIA
}

\author{
Verina Christi ${ }^{1}$ \\ Munari $^{2}$ \\ 1,2Universitas Pembangunan Nasional "Veteran” Jawa Timur, Jawa Timur, \\ Indonesia \\ email : verina.christi17@gmail.com
}

\begin{abstract}
ABSTRAK
Penelitian ini memiliki tujuan yaitu untuk mengetahui adanya pengaruh rasio keuangan terhadap harga saham di perusahaan rokok yang terdaftar di Bursa Efek Indonesia selama periode triwulan I tahun 2017 - IV tahun 2019, baik secara parsial maupun simultan. Rasio keuangan yang diteliti antara lain quick ratio (QR), net profit margin (NPM), total asset turnover (TATO), dan debt to asset ratio (DAR). Sampel penelitian sebanyak 4 perusahaan rokok yang diperoleh dengan teknik purposive sampling. Teknik pengumpulan data yang digunakan adalah dokumentasi dan studi kepustakaan. Analisis data dilakukan dengan teknik analisis regresi linear berganda. Hasil penelitian menunjukkan bahwa secara parsial variabel QR, NPM, dan DAR berpengaruh signifikan terhadap harga saham, sedangkan TATO tidak berpengaruh terhadap harga saham. Secara simultan variabel QR, NPM, TATO, dan DAR berpengaruh terhadap harga saham.
\end{abstract}

Kata kunci: : Harga Saham; QR; NPM; TATO; DAR

\begin{abstract}
The objective of this study is to determine the effect of financial ratios on stock prices in cigarette companies listed in Bursa Efek Indonesia (Indonesia Stock Exchange) during the first quarter of 2017 until the last quarter of 2019, either partially or simultaneously. The financial ratio being examined in this study include quick ratio (QR), net profit margin (NPM), total asset turnover (TATO), and debt to asset ratio (DAR). The population of this study was the cigarette companies listed in Indonesia Stock Exchange in the first quarter of 2017 until the last quarter of 2019. The research sample was 4 cigarette companies obtained by purposive sampling technique. The data collection techniques that used were documentation and literature study. Data analysis was performed using multiple linear regression analysis techniques. The results of this study showed that partially $Q R, N P M$, and DAR variables have a significant effect on stock prices, while TATO has no effect on stock prices. Simultaneously the QR, NPM, TATO, and DAR variables affect the stock prices.
\end{abstract}

Keywordsi: Harga Saham; QR; NPM; TATO; DAR 


\section{PENDAHULUAN}

Banyaknya variasi teknologi dan informasi, meningkatkan minat masyarakat dalam mencari inovasi kegiatan ekonomi. Salah satu pasar penggerak perekonomian negara yaitu perusahaan rokok. Perusahaan rokok menggunakan baku yang terdiri atas tembakau dan cengkeh yang sebagian besar ditanam di dalam negeri seperti provinsi Jawa Timur, Nusa Tenggara Barat, Jawa Tengah, Jawa Barat, serta Sumatera Utara. Dalam hal ini kegiatan penggunaan sumber daya alam yang dilakukan di dalam negara, dapat menjadikan salah satu penerimaan kas terbesar di Indonesia.

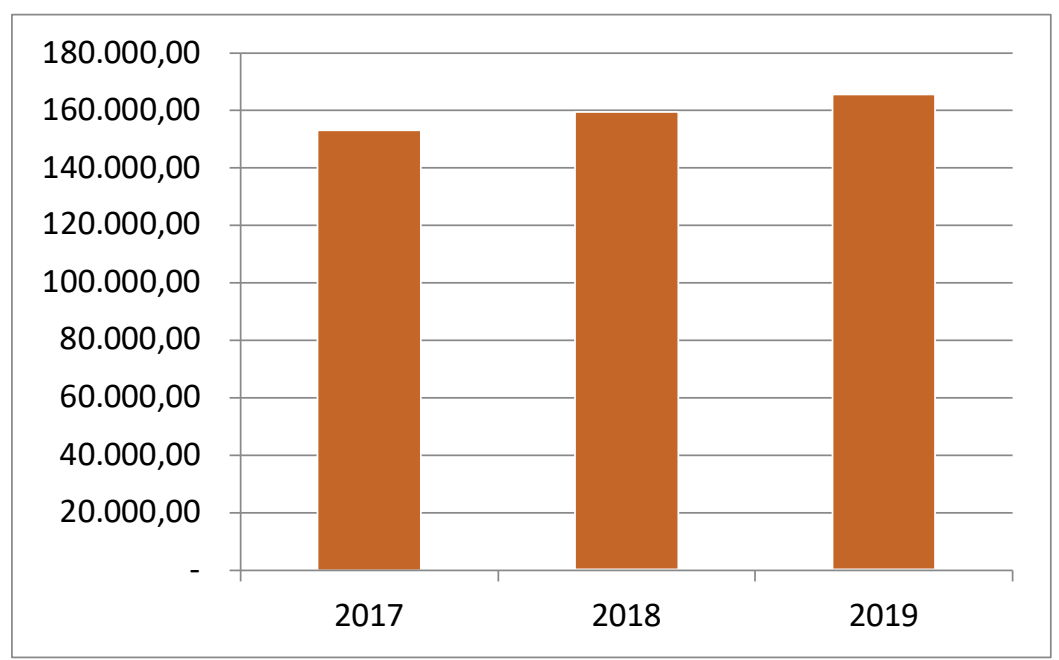

\section{Gambar 1. Grafik Realisasi Penerimaan Cukai Negara}

Sumber: Olahan data, Badan Pusat Statistik, 2021

Realisasi penerimaan cukai yang terdapat dalam gambar 1, menggambarkan bahwa pada di tahun 2017 penerimaan cukai di Indonesia sebesar Rp 153.288,10 (dalam jutaan), perusahaan rokok menyumbang atas cukai Negara senilai 149.900 (dalam jutaan), dapat diartikan bahwa industi rokok memberikan 97,8\% dari total seluruh realisasi cukai. Di tahun 2018 penerimaan kas negara Indonesia atas cukai sebesar Rp 159.588,60 (dalam jutaan), cukai rokok sendiri menyumbang sebanyak Rp 152.900 (dalam jutaan) dalam hal ini perusahaan rokok membayar sebesar 95,8\% atas total penerimaan cukai negara, Sedangkan realisasi penerimaan cukai di negara Indonesia tepatnya tahun 2019 sebesar Rp 165.760 (dalam jutaan), cukai rokok sendiri menyumbang sebanyak Rp 125.020 (dalam jutaan) berdasarkan data tabel di atas penerimaan cukai rokok mengalami penurunan sebesar $2 \%$ dari tahun 2017 terhadap tahun 2018 dan men mengalami penurunan presentase sebesar $75.4 \%$ namun, cukai rokok masih mendominasi pendapatan atas cukai Negara (Badan Pusat Statistik, 2021). Perusahaan rokok mempunyai pengaruh yang besar dalam meningkatkan perekonomian negara dalam penerimaan cukai. Adapun Perusahaan rokok yang telah terdaftar di bursa efek Indonesia yakni PT. Gudang Garam Tbk. (GGRM), PT. Hanjaya Mandala Sampoerna Tbk. (HMSP), PT. Bentoel Internasional Investama Tbk. (RMBA), dan PT. Wismilak Inti Makmur Tbk. (WIIM). Yang memiliki jumlah impor terbayak seperti pada negara Tiongkok (46.007,4 kg), Brazil (21.064,8 kg), Amerika Serikat (40.674.8 kg), dan lain-lain. Sedangkan kegiatan ekspor dilakukan ke berbagai negara antara lain Sri Lanka 
(1.086 kg), Amerika Serikat (2.827,3 Kg), Republik Dominika (753,3 kg), dan lainlain (Detik Finance, 2019).

Adanya kegiatan perekonomian yang meningkat khususnya pada kegiatan ekspor, impor dan investasi akan memacu pertumbuhan ekonomi (Kholis et al., 2016). Dengan demikian total kemampuan ekspor dan impor perusahaan rokok sangat besar untuk menopang penerimaan kas negara.

Tabel 1.

Daftar Laba Bersih Perusahaan Rokok yang terdaftar di BEI

\begin{tabular}{lccc}
\hline \multicolumn{1}{c}{ Nama Perusahaan } & \multicolumn{3}{c}{ Laba Perusahaan (dalam jutaan rupiah) } \\
\cline { 2 - 4 } & $\mathbf{2 0 1 7}$ & $\mathbf{2 0 1 8}$ & $\mathbf{2 0 1 9}$ \\
\hline PT. Gudang Garam Tbk & 7.755 .346 & 7.793 .068 & 10.880 .704 \\
PT. Hanjaya Mandala Sampoerna Tbk & 12.670 .534 & 13.538 .418 & 12.721 .513 \\
PT. Bantoel Internasional Investama & $(480.063)$ & $(608.463)$ & 50.612 \\
PT. Wismilak Inti Makmur & 40.590 & 51.142 & 27.328 \\
\hline
\end{tabular}

Sumber: Bursa Efek Indonesia (www.idx.com)

Dalam Tabel 1. laba yang didapatkan pada Bursa Efek Indonesia mencatat bahwa PT. Gudang Garam Tbk, PT. Hanjaya Mandala Sampoerna Tbk.. Wismilak Inti Makmur Tbk memiliki laba yang meningkat dari tahun 2017 hingga 2019. Sedangkan pada PT. Bentoel Internasional Investama mempunyai penghasilan laba yang berfluktuasi, dimana pada tahun 2017 hingga tahun 2018 mengalami kerugian sebesar - Rp. 480.063 dan - Rp 608.463 (dalam jutaan) hal ini disebabkan peningkatan tarif atas cukai sebesar $10 \%$ dan penurunan kegiatan operasional dan dari kegiatan pasar rokok di Indonesia. Keuntungan besar yang dihasilkan oleh perusahaan menjadi salah satu daya tarik bagi investor yang akan menanamkan dana (Tempo Bisnis, 2018).

Kegiatan ekspor dan impor yang besar, dapat menjadi salah satu daya Tarik investor di perdagangan pasar modal. Pasar modal merupakan tempat terjadinya perdagangan instrumen keuangan baik dalam jangka waktu panjang maupun jangka pendek (Untung, 2011). Harga saham yang terdapat di pasar modal merupakan suatu gambaran atas kemampuan perusahaan dalam kinerja keuangan dengan tujuan yakni mencari keuntungan dalam kegiatan produksi an operasional perusahaan selama jangka waktu tertentu, semakin tinggi harga saham disebabkan oleh tingginya permintaan baik pembelian atas pembelian saham dari investor (Astuti, 2018).

Dalam Gambar 2. harga saham memiliki sifat fluktuatif atau dapat naik ataupun turun serta bervariasi dapat dipengaruhi oleh beberapa factor, baik internal maupun eksternal. Factor internal terdiri atas informasi arus kas, informasi laba, rasio keuangan, dan infromasi lain yang terdapat dalam laporan tahunan perusahaan. Factor ekstenal yang dapat mempengaruhi harga saham meliputi tingkat bunga, transaksi saham, kebijakan makro ekonomi yang ditetapkan oleh pemerintah suatu negara dan kondisi sosial serta politik negara.

Guna membantu investor dalam meminimalisir resiko yang mungkin dapat terjadi di masa yang akan datang, maka dapat dilakukan dengan dua analisis yaitu analisis fundamental (fundamental security analysis) dan analisis teknikal (company analysis). Analisis teknikal merupakan suatu proses dengan data pasar 
dari saham, sedangkan analisis fundamental merupakan suatu proses dengan data dari laporan keuangan perusahaan (Adipalguna, 2016).

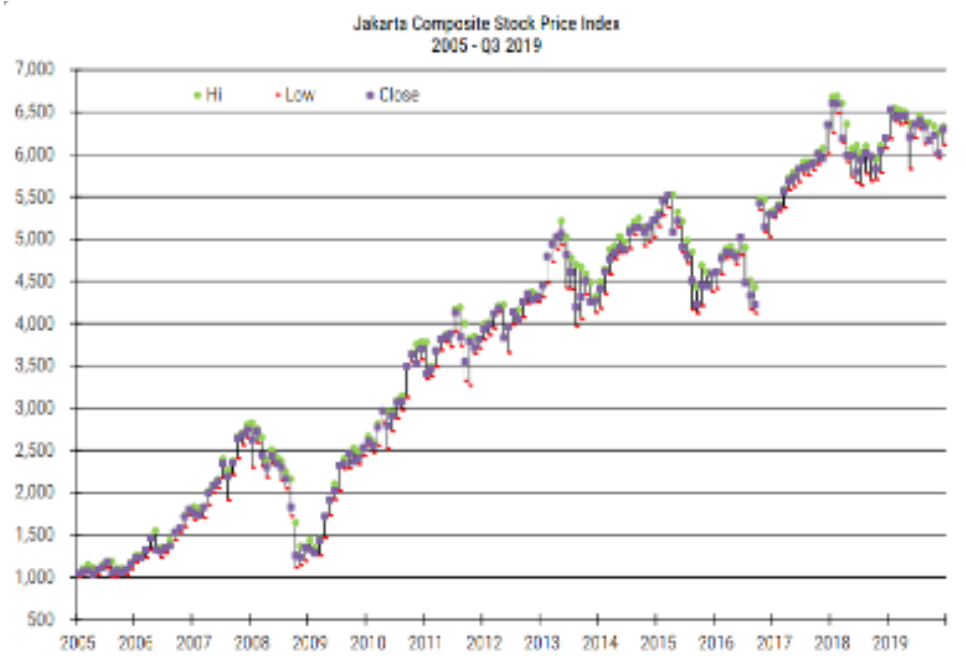

Gambar 2. Grafik Perkembangan Harga Saham di Indonesia

Sumber: Bursa Efek Indonesia (www.idx.com)

Dalam analisis fundamental laporan keuangan mempunyai manfaat bagi pihak yang memangku kepentingan baik pihak perusahaan seperti, pimpinan perusahaan, manajemen perusahaan dan karyawan perusahaan. Bagi pihak luar perusahaan, laporan keuangan dijadikan suatu alat yang menjadi basis dalam melihat keuntungan dari perusahaan tersebut, kinerja perusahaan tersebut serta untuk menanamkan modal yang dimiliki oleh investor. Kinerja keuangan merupakan salah satu aspek yang sangat penting bagi investor karena dianggap sebagai tingkat keberhasilan suatu perusahaan, baik kondisi di masa yang akan datang dengan informasi keuangan perusahaan dalam laporan keuangan (Sari \& Santoso, 2017).

Laporan keuangan perusahaan memiliki fungsi-fungsi keuangan yang dianalisis merupakan pengkajian pos-pos laporan keuangan yang memberikan informasi hubungan spesifik antara satu dengan yang lain. Kegunaan analisis laporan keuangan yakni sebagai salah satu alat dan dasar dalam menilai kinerja perusahaan yang telah berlalu dari suatu proses kegiatan operasional perusahaan serta posisi keuangan yang telah dilaporkan oleh perusahaan baik dalam masa sekarang dan dapat menilai kemampuan perusahaan tersebut dalam mendapatkan keuntungan bagi masa depan (Pohan, 2017). Dengan demikian, laporan keuangan memiliki manfaat bagi menilai kinerja perusahaan baik masa depan maupun masa sekarang. Bagi analis keuangan, laporan keuangan merupakan salah satu alat yang dapat digunakan untuk mengukur rasio keuangan.

Rasio keuangan terdiri atas rasio likuiditas, profitabilitas, aktivitas dan solvabilitas. Rasio likuiditas atau rasio modal kerja mencerminkan kemampuan kinerja keuangan suatu perusahaan dalam memenuhi kewajiban jangka pendek, 
yang artinya rasio ini memiliki manfaat untuk mengukur seberapa likuidnya perusahaan dengan cara membandingkan aktiva lancar dengan kewajiban. Rasio profitabilitas merupakan salah satu rasio yang memiliki manfaat dalam menilai kemampuan kinerja perusahaan dalam mendapatkan keuntungan, serta rasio profitabilitas dapat mengidentifikasi apakah suatu perusahaan tersebut telah melakukan manajemen yang efektif dalam memperoleh keuntungan. Rasio aktivitas merupakan rasio yang memiliki manfaat bagi perusahaan dalam mengukur kemampuannya dalam memanfaatkan dan memaksimalkan sumber daya perusahaan secara efektif. Rasio solvabilitas memiliki manfaat dalam menilai perusahaan dengan elemen laporan keuangan yaitu hutang jangka pendek maupun jangka panjang yang dimiliki dan dibayarkan dengan aktiva perusahaan, sehingga sumber-sumber dana yang digunakan dalam perusahaan baik hutang maupun modal sendiri dapat dipertanggungjawabkan (Kasmir, 2014).

Analisis rasio keuangan dapat digunakan untuk menilai suatu proses kegiatan keuangan yang dilakukan oleh perusahaan yang diwujudkan dalam bentuk dalam laporan keuangan terkait dengan pos-pos akuntansi yang di dalamnya terkandung angka-angka yang setiap elemen laporan keuangan yang terdiri dari: laporan laba rugi, laporan posisi keuangan, laporan perubahan modal, neraca, arus kas, serta catatan atas laporan keuangan (Kasmir, 2014).

Rasio keuangan yang dapat membantu para investor maupun analis dalam menganalisis laporan keuangan dapat diketahui dengan adanya teori signal. Laporan keuangan yang disajikan oleh perusahaan baik laporan keuangan tahunan ataupun triwulan merupakan salah satu sinyal positif yang diberikan oleh perusahaan dalam memberikan informasi maupun salah satu langkan dalam mengurangi asimetri informasi yang terjadi. Pemberian sinyal ini menjadikan salah satu daya tarik bagi pihak eksternal dalam menilai kinerja keuangan dengan melihat elemen-elemen yang terkandung dalam laporan keuangan (Atonius \& Muchamad, 2013).

Informasi-informasi yang diberikan dalam laporan keuangan yang mencakup gambarkan kondisi mengenai kegiatan keuangan perusahaan yang mencakup jenis dan jumlah aktiva, menggambarkan kondisi mengenai kegiatan keuangan perusahaan yang mencakup jenis dan jumlah kewajiban serta ekuitas, menggambarkan kondisi mengenai kegiatan keuangan perusahaan yang mencakup penjualan maupun pendapatan dan menggambarkan kondisi mengenai kegiatan keuangan perusahaan yang mencakup biaya operasional dan administrasi (Kasmir, 2014).

Rasio pertama yang digunakan dalam penelitian ini yaitu quick ratio (QR) merupakan hasil total aktiva lancar yang telah dikurangi dengan persediaan dibandingkan dengan keseluruhan hutang lancar yang akan segera jatuh tempo yang dimiliki oleh perusahaan. Quick ratio ini menunjukan kecakapan perusahaan menyelesaikan hutang lancar yang segera jatuh tempo pada tahun tertentu menggunakan aset perusahaan yang sangat lancar (Purba, 2019), yang artinya tingkat likuiditas perusahaan mencerminkan suatu tingkat return saham terhadap likuiditas asset yang dimiliki oleh perusahaan dan terdapat suatu pengaruh yang cukup besar jika likuiditas perusahanan tersebut mengalami perubahan, maka harga saham perusahaan ikut terpengaruhi (Vivekananda et al., 2019). Hal ini sesuai 
dengan teori sinyal, yang dimana laporan keuangangan memiliki fungsi dalam memberikan informasi mengenai rasio cepat atau quick ratio. Ditunjukkan dalam adanya elemen nilai yang terkandung dalam quick ratio dapat mempengaruhi tingkat perdagangan harga saham, sehingga harga saham juga meningkat, sehingga hipotesisnya menjadi:

$\mathrm{H}_{1}$ : Quick ratio berpengaruh positif signifikan terhadap harga saham.

Sedangkan rasio kedua yaitu net profit margin (NPM) adalah hasil dari perbandingan antara laba bersih dengan penjualan. Net profit margin menggambarkan kinerja perusahaan menghasilkan keuntungan (Sari \& Santoso, 2017), yang dimana tingkat profitabilitas suatu perusahaan yang tinggi juga akan meningkatkan pendapatan investor atas return saham (Amalya, 2018). Teori yang berkaitan dengan hubungan Net Profit Margin (NPM) yaitu teori sinyal, salah satu alat yang digunakan oleh investor adalah laporan keuangan, dan dalam laporan keuangan elemen atau pos yang diperhatikan adalah laba yang didapatkan oleh perusahaan. Laporan keuangan ini diterbitkan oleh perusahaan sebagai salah satu sinyal positif untuk mencari investor atau penanam modal dengan memperhatikan pos-pos laporan keuangan, sehingga hipotesisnya menjadi:

$\mathrm{H}_{2}$ : Net profit margin berpengaruh positif signifikan terhadap harga saham.

Rasio ketiga yaitu total asset turnover (TATO) merupakan hasil atas penjualan dengan total aktiva. Nilai dari rasio ini digunakan untuk menghitung total penjualan yang didapatkan dari tiap aktiva (Cathelia \& Sampurno, 2016), yang dimana kegiatan yang dilakukan perusahaan dalam penjualan semakin lama semakin meningkat maka akan meningkatkan dalam memperoleh keuntungan. Dengan keuntungan yang meningkat maka investor akan menanamkan modalnya ke dalam perusahaan tersebut. Modal yang dimiliki oleh perusahaan semakin meningkat yang disebabkan oleh investor menanamkan modalnya, maka akan berpengaruh pada harga saham yang akan meningkat pula (Adipalguna, 2016). Hubungan total asset turn over (TATO) terhadap harga saham sangat dipengaruhi oleh adanya laporan keuangan yang terapat pos penjualan dan total asset perusahaan yang dimiliki oleh perusahaan. Laporan keuangan terdiri dari pos-pos yang menggambarkan suatu nilai atas kegiatan ekonomi yang dilakukan oleh perusahaan dalam mendapatkan keuntungan. Laporan keuangan ini merupakan salah satu media yang di lakukan oleh investor dalam menganalisis dan mendapatkan sinyal positif dari perusahaan terkait, sehingga hipotesisnya menjadi:

$\mathrm{H}_{3}$ : Total asset turnover berpengaruh positif signifikan terhadap harga saham.

Sedangkan rasio keempat yaitu debt to asset ratio (DAR) menggambarkan hasil perbandingan antara total hutang dengan total aktiva perusahaan. Nilai dari rasio ini digunakan untuk mengukur kemampuan perusahaan dalam membiayai maupun melunasi kewajiban yang ditanggung oleh perusahaan dengan aset yang dimiliki oleh perusahaan (Daniel, 2015), harga saham semakin meningkat jika suatu perusahaan memiliki kemampuan dalam melunasi hutang yang dimiliki, oleh karena itu tingkat rasio solvabilitas khususnya debt to assets ratio yang dimiliki oleh suatu perusahaan semakin kecil maka tingkat profitabilitas suatu perusahaan tersebut akan meningkat akibat hutang yang semakin menurun (Damayanti \& Valianti, 2016). Hubungan Debt To Asset Ratio (DAR) terhadap harga saham yaitu salah satu ketertarikan investor dalam membeli instrumen keuangan dengan melihat 
pos-pos laporan keuangan yang berkaitan dengan hutang jangka pendek dan asset lancar yang dimiliki. Ketertarikan ini dikarenakan adanya informasi-informasi yang relevan dengan kondisi keuangan perusahaan yaitu laporan keuangan, sehingga hipotesisnya menjadi:

$\mathrm{H}_{4}$ : Debt to asset ratio berpengaruh positif signifikan terhadap harga saham.

Berdasarkan hasil dari penelitian terdahulu mengenai quick ratio, net profit margin, total asset turnover, dan debt to asset ratio mempengaruhi harga saham secara signifikan pada tahun dan perusahaan yang berbeda, maka peneliti tertarik dalam mengkaji ulang rasio-rasio pada perusahaan rokok periodekuaral I tahun 2017 sampai dengan kuarta; IV tahun 2019.

\section{METODE PENELITIAN}

Pendekatan dalam yang digunakan dalam penelitian yaitu asosiatif dengan adanya hubungan antara variabel independen yang terdiri dari Quick Ratio (QR), Net Profit Margin (NPM), Total Asset Turnover (TATO), dan Debt to Assets Ratio (DAR) dan dependen yaitu harga saham (HS) (Sugiyono, 2018). Dengan jenis data kuantitatif. data sekunder atau nilai-nilai yang didapat dari website Bursa Efek Indonesia (Bursa Efek Indonesia, 2021).

Sampel penelitian berjumlah berjumlah 4 (empat) perusahaan pada kuartal I tahun 2017 sampai dengan kuartal IV tahun 2019 dari perusahaan rokok. Teknik penarikan sampel adalah purposive sampling dengan pertimbangan yaitu: perusahaan rokok yang tercatat di Bursa Efek Indonesia periode Kuartal I 2017 sampai dengan Kuartal IV 2019, data laporan keuangan yang tersedia berturut-turut untuk laporan kuartal I tahun 2017 sampai dengan kuartal IV tahun 2019 laporan keuangan dalam bentuk mata uang Rupiah, dan Nilai harga saham per akhir kuartal menggunakan data dari website Bursa Efek Indonesia, terdapat 12 Kuartal dalam tiap perusahaan.

Tabel 2.

Daftar Sampel Penelitian

\begin{tabular}{ccc}
\hline No. & Kode Saham & Nama Emiten \\
\hline 1 & GGRM & PT. Gudang Garam Tbk. \\
2 & HMSP & PT. Hanjaya Mandala Sampoerna Tbk. \\
3 & RMBA & Bantoel Internasional Investama Tbk. \\
4 & WIIM & Wismilak Inti Makmur Tbk. \\
\hline
\end{tabular}

Sumber: Bursa Efek Indonesia, 2021

Rasio cepat (quick ratio) merupakan rasio yang digunakan untuk membandingkan antara aktiva lancar dikurangi dengan persediaan dengan utang lancar (Kasmir, 2014), hal ini dimaksudkan karena persediaan merupakan asset yang dimiliki oleh perusahaan tidak bersifat likuid dan perlu memerlukan waktu untuk merubah menjadi asset likuid perusahaan. QR dapat dihitung dengan rumus:

$Q R=\frac{\text { Aktiva Lancar }- \text { Persediaan }}{\text { Hutang Lancar }}$ 
Net profit margin, rasio yang berfungsi sebagai salah satu alat ukur dalam menilai margin laba atas penjualan yang dihasilkan oleh perusahaan (Kasmir, 2014), net profit margin memiliki fungsi atau manfaat untuk mengukur seberapa besar penjualan yang dihasilkan dan dilakukan oleh perusahaan dalam menghasilkan laba perusahaan, yang dimana laba tersebut merupakan salah satu daya Tarik investor untuk menanamkan modal atau dana yang dimilikinya. NPM dapat dihitung dengan rumus:

$N P M=\frac{\text { Laba Bersih }}{\text { Penjualan }}$

Perputaran aktiva (total asset turnover), merupakan rasio aktivitas yang memiliki kegunaan sebagai pengukuran kemampuan seluruh aktiva perusahaan dengan jumlah penjualan yang dihasilkan oleh perusahaan dalam periode tertentu (Kasmir, 2014), total asset turnover (TATO) memiliki tujuan untuk mengetahui kemampuan perusahaan dalam memanfaatkan dan mengunakan asset yang dimiliki secara efektif dan efisien dengan tujuan melihat nilai penjualan perusahaan. TATO dapat dihitung dengan rumus:

TATO $=\frac{\text { Penjualan }}{\text { Total Aset }}$

Debt to assets ratio (DAR), rasio ini digunakan untuk menilai perbandingan antara total utang yang dimiliki oleh perusahaan dengan total keseluruhan aktiva perusahaan (Kasmir, 2014), debt to assets ratio (DAR) memiliki manfaat sebagai salah satu alat analisis rasio dengan melihat seluruh kewajiban perusahaan yang akan segera jatuh tempo dengan kemampuan pembayaran aktiva atau asset perusahaan. DAR dapat dihitung dengan rumus:

$D A R=\frac{\text { Total Hutang }}{\text { Total Aset }}$

Dalam penelitian ini menggunakan data time series dengan menggunakan program SPSS 23. Beberapa teknik analisis data yakni uji normalitas, uji asumsi klasik yang terdiri atas uji multikolonieritas, uji autokorelasi, uji heteroskedastisitas. Serta Teknik analisis data yang dilakukan yaitu model analisis regresi linear berganda, dengan persamaan sebagai berikut:

$\mathrm{Y}=\alpha+\beta_{1} \mathrm{X}_{1}+\beta_{2} \mathrm{X}_{2}+\beta_{3} \mathrm{X}_{3}+\beta_{4} \mathrm{X}_{4}+\mathrm{e}$.

Keterangan :

$\begin{array}{ll}\mathrm{Y} & : \text { Harga Saham } \\ \mathrm{X}_{1} & : \text { Quick Ratio } \\ \mathrm{X}_{2} & : \text { Net Profit Margin } \\ \mathrm{X}_{3} & : \text { Total Assets Turnover } \\ \mathrm{X}_{4} & : \text { Debt to Assets Ratio } \\ \alpha & : \text { Konstanta } \\ \beta_{1}, \beta_{2}, \beta_{3}, \beta_{4} & : \text { Koefisisen yaitu yang melekat pada suatu nilai variabel } \\ \mathrm{e} & : \text { Variabel pengganggu atau error }\end{array}$




\section{HASIL DAN PEMBAHASAN}

Statistik deskriptif digunakan untuk mengetahui karakteristik sampel dalam penelitian meliputi mean, nilai maksimum, nilai minimum, dan standar deviasi. Berikut ini adalah hasil dari uji deskriptif data dari seluruh sampel.

Tabel 3.

Hasil Analisis Statistik Deskriptif Data

\begin{tabular}{ccccc}
\hline & Mean & Maximum & Minimum & Std. Dev \\
\hline Harga Saham & $18.632,04$ & 83.800 & 141 & $30.880,84$ \\
QR & 1,10 & 2,58 & 0,26 & 0,73 \\
NPM & 0,53 & 0,15 & $-0,06$ & 0,06 \\
TATO & 0,95 & 2,30 & 0,24 & 0,51 \\
DAR & 0,34 & 1,03 & 0,20 & 0,13 \\
\hline
\end{tabular}

Sumber: Output SPSS, 2021

Berdasarkan Tabel 3. Harga Saham (Y) merupakan harga penutupan pasar saham selama periode pengamatan yaitu harga terakhir atau harga penutupan setiak akhir periode triwulan. Harga saham dengan jumlah data $(\mathrm{N})$ sebanyak 48 sampel memiliki nilai minimum 141, untuk niai tertinggi (maximum) sebesar 83.800. Nilai rata-rata harga saham 18.632,04, sedangkan nilai standar deviasinya sebesar $30.880,84$.

Rasio pertama yaitu Quick Ratio (QR) merupakan rasio untuk mengukur kinerja perusahaan dalam melunasi hutang jangka pendek yang akan segera jatuh tempo dengan aset likuid perusahaan, tidak termasuk persediaan yang dimiliki oleh perusahaan. Dengan jumlah data $(\mathrm{N})$ sebanyak 48 sampel memiliki nilai minimum 0,26 , untuk niai tertinggi (maximum) sebesar 2,58. Nilai rata-rata quick ratio sebesar 1,10, sedangkan nilai standar deviasinya sebesar 0,73.

Rasio kedua yaitu Net Profit Margin (NPM) merupakan rasio untuk mengukur kinerja perusahaan dalam mendapatkan laba bersih dengan tingat penjualan tertentu yang dihasilkan oleh perusahaan dalam jangka waktu tertentu. Dengan jumlah data $(\mathrm{N})$ sebanyak 48 sampel memiliki nilai minimum -0,06, untuk niai tertinggi (maximum) sebesar 0,15. Nilai rata-rata Net Profit Margin sebesar 0,53 , sedangkan nilai standar deviasinya sebesar 0,06 .

Rasio ketiga yaitu Total Assets Turnover (TATO) merupakan rasio untuk mengukur kinerja perusahaan dalam mendapatkan penjualan yang besar Dengan seluruh kepemilikan aktiva perusahaan. dengan jumlah data $(\mathrm{N})$ sebanyak 48 sampel memiliki nilai minimum 0,24, untuk niai tertinggi (maximum) sebesar 2,30. Nilai rata-rata Total Assets Turnover sebesar 0,95, sedangkan nilai standar deviasinya sebesar 0,51. Rasio keempat yaitu Debt to Assets Ratio (DAR) merupakan rasio untuk mengukur kinerja perusahaan dalam melunasi seluruh hutang perusahaan dengan seluruh nilai aset perusahaan yang dimilikinya. Dengan jumlah data $(\mathrm{N})$ sebanyak 48 sampel memiliki nilai minimum 0,20 untuk niai tertinggi (maximum) sebesar 1,03. Nilai rata-rata Total Assets Turnover sebesar 0,34 , sedangkan nilai standar deviasinya sebesar 0,13 . 


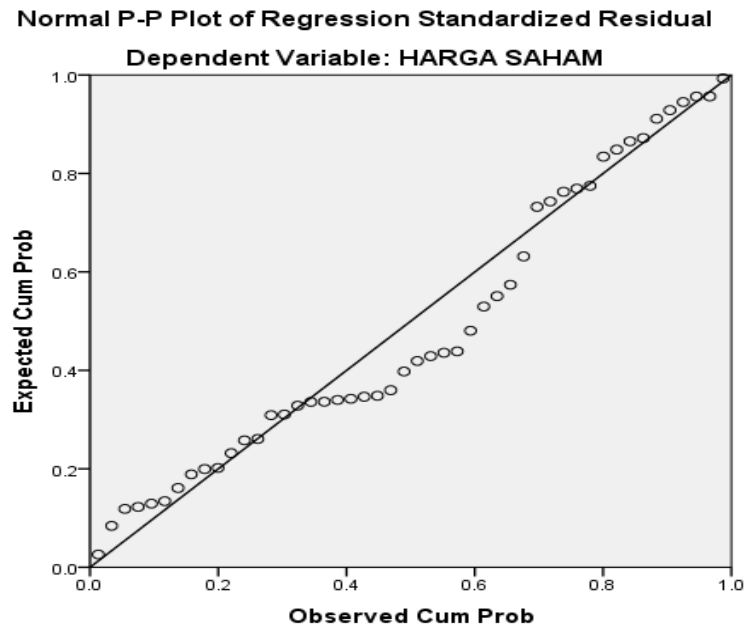

\section{Gambar 2. Hasil Uji Normalitas}

Sumber: Output SPSS, 2021

Uji normalitas pada digunakan untuk mendeteksi apakah dalam sebuah model regresi terdapat variabel dependen yang memiliki distribusi normal atau tidak. Uji normalitas dilakukan dengan grafik P-P-Plot (Plot of Regression Standardized residual). Hasil dalam grafik $P$-P-Plot yang didapatkan harus menghasilkan titiktitik distribusi yang berada di sekitar garis harus diagonal dan harus menyebar seiring mengikuti garis diagonal, maka model regresi tersebut telah memenuhi asumsi normal (Ghozali, 2016).

Berdasarkan Gambar 2, menunjukkan data menyebar di sekitar garis diagonal dan mengikuti arah garis diagonal. Hal ini menunjukkan bahwa regresi memenuhi syarat normalitas.

Tabel 4.

Hasil Uji Multikolinearitas

\begin{tabular}{ccc}
\hline $\begin{array}{c}\text { Model } \\
\text { (Constant) }\end{array}$ & Tolerance & VIF \\
\hline QR & & 1,441 \\
NPM & 0,694 & 1,264 \\
TATO & 0,791 & 1,203 \\
DAR & 0,831 & 1,314 \\
\hline
\end{tabular}

Sumber: Data diolah, 2021

Uji multikolonieritas memiliki tujuan yaitu untuk menguji data dengan adanya temuan gejala korelasi antara variabel bebas.. Multikolonieritas kan muncul ketika terdapat korelasi pada variabel-variabel independen (Ghozali, 2016), dengan kriteria nilai tolerance $>0,1$ dan $\mathrm{VIF}<10$. 
Dalam Tabel 4, hasil QR memiliki nilai tolerance sebesar 0,694 dan nilai VIF sebesar 1,441. Untuk NPM memiliki nilai tolerance sebesar 0,791 dengan nilai VIF 1,264 . Rasio berikutnya yaitu TATO dengan nilai tolerance 0,831 dengan nilai VIF 1,203. Rasio terakhir yaitu DAR dengan menghasilkan nilai tolerance 0,761 dan nilai VIF 1,314, maka data regresi tidak terjadi gejala multikolinearitas antar variabel independen.

Tabel 5.

Hasil Uji Autokorelasi

\begin{tabular}{cc}
\hline & Unstandarardiz ed Residual \\
\hline Test Value & -3753.57356 \\
Cases $<$ Test Value & 24 \\
Cases $>=$ Test Value & 24 \\
Total Cases & 48 \\
Number of Runs & 20 \\
Z & -1.313 \\
Asymp. Sig (2-tailed) & .189 \\
\hline
\end{tabular}

Sumber: Output SPSS, 2021

Uji autokorelasi bertujuan untuk menguji apakah model regresi linear memiliki hubungan atau korelasi antara kesalahan penganggu pada periode $\mathrm{t}$ dengan kesalahan pengganggu pada periode t-1 pada periode sebelumnya (Ghozali, 2016). Tabel 5, menunjukkan nilai Sig. 0,189 atau 18,9\% yang memiliki arti bahwa lebih besar dari 5\%, maka tidak terjadi gejala autokorelasi. Dengan demikian, dapat memenuhi salah satu syarat uji asumsi klasik.

Tabel 6.

Hasil Uji Heteroskedastisitas

\begin{tabular}{cccccc}
\hline Model & \multicolumn{2}{c}{ Unstandardized Coefficients } & $\begin{array}{c}\text { Standardized } \\
\text { Coefficients }\end{array}$ & t & Sig. \\
\cline { 2 - 4 } & B & Std. Error & Beta & & \\
\hline (Constant) & 14720.604 & 5332.878 & & 2.760 & .008 \\
QR & -309.951 & 2113.145 & -.026 & -.147 & .884 \\
NPM & 28482.910 & 22736.637 & .207 & 1.253 & .217 \\
TATO & 47.299 & 2742.105 & .003 & .017 & .986 \\
DAR & -9824.797 & 11244.203 & -.147 & -.074 & .387 \\
\hline
\end{tabular}

Sumber: Output SPSS, 2021

Uji heterokedastisitas bertujuan untuk mendeteksi terjadinya ketidaksamaan varian dan residual pada satu pengamatan ke pengamatan yang lain (Ghozali, 2016).

Dalam Tabel 6, menghasilkan nilai signifikansi nilai lebih besar dari 0,05 atau 5\%, dengan hasil nilai signifikansi Quick Ratio (QR) sebesar 0.884 atau sebesar 88,4\%. Sedangkan untuk hasil dari Net Profit Margin (NPM) sebesar 0.217 atau sebesar 21,7\%. Total asset turnover (TATO) dengan nilai signifikansi sebesar 0.986 atau sebesar 98,6\%. Untuk variabel debt to asset ratio (DAR) memiliki nilai signifikansi sebesar 0.387 atau sebesar 38,7\%. Dengan artu lain dari hasil tiap variabel tidak terjadi gejala heteroskedasitidas dan telah memenuhi syarat uji asumsi klasik. 
Tabel 7.

Pengujian Regresi

\begin{tabular}{cccccc}
\hline $\begin{array}{c}\text { Variabel } \\
\text { Dependen }\end{array}$ & $\begin{array}{c}\text { Variabel } \\
\text { Independen }\end{array}$ & $\begin{array}{c}\text { Koefisien } \\
\text { Regresi }\end{array}$ & t-statistic & Sig. & $\mathbf{R}^{\mathbf{2}}$ \\
\hline Harga & (Constant) & 61041,236 & 6,226 & 0,000 & 0,749 \\
Saham & QR & $-38445,717$ & $-9,896$ & 0,000 & \\
& NPM & 298939,055 & 7,151 & 0,000 & \\
& TATO & $-766,446$ & -0.152 & 0,880 & \\
& DAR & $-45698,016$ & $-2,211$ & 0,032 & \\
\hline & F-statistik & 32,006 & & \\
\hline
\end{tabular}

Sumber: Data diolah, 2021

Tabel 7. menghasilkan nilai analisis regresi linear berganda dengan koefisien determinasi $\left(\mathrm{R}^{2}\right)$ sebesar 0,749 atau $74,9 \%$. Dalam hal tersebut berarti bahwa kemampuan variabel-variabel Quick Ratio (QR), Net Profit Margin (NPM), Total Assets Turnover (TATO), dan Debt to Assets Ratio (DAR) mempunyai pengaruh sebesar 0.749 atau sebesar $74,9 \%$ terhadap harga saham. Sedangkan sebesar 0.251 atau sebesar $25,1 \%$ lainnya dipengaruhi variabel lainnya yang tidak digunakan dalam penelitian ini.

Tabel 8.

Hasil Uji t (Uji Parsial)

\begin{tabular}{|c|c|c|c|c|c|}
\hline \multirow{2}{*}{ Model } & \multicolumn{2}{|c|}{ Unstandardized Coefficients } & \multirow{2}{*}{$\begin{array}{c}\begin{array}{c}\text { Standardized } \\
\text { Coefficients }\end{array} \\
\text { Beta } \\
\end{array}$} & \multirow[t]{2}{*}{$\mathbf{t}$} & \multirow[t]{2}{*}{ Sig } \\
\hline & B & Std. Error & & & \\
\hline (Constant) & 14720.604 & 5332.878 & & 2.760 & .008 \\
\hline QR & -309.951 & 2113.145 & -.026 & -.147 & .884 \\
\hline NPM & 28482.910 & 22736.637 & .207 & 1.253 & .217 \\
\hline TATO & 47.299 & 2742.105 & .003 & .017 & .986 \\
\hline DAR & -9824.797 & 11244.203 & -.147 & -.874 & .387 \\
\hline
\end{tabular}

Sumber: Output SPSS, 2021

Uji t pada Tabel 8. memiliki manfaat untuk menilai rasio keuangan berpengaruh signifikan terhadap harga saham atau variabel dependen lain (Ghozali, 2016). Uji t statistik dilakukan untuk mengetahui apakah variabel bebas secara individual mempunyai pengaruh terhadap variabel terikat dengan asumsi variabel yang lain yaitu konstan.

Variabel pertama memiliki nilai uji t untuk variabel Quick Ratio (QR) sebesar $-9,896$ dengan nilai signifikansi 0,000. Nilai signifikansi tersebut lebih kecil dari 0,05 sehingga dapat disimpulkan bahwa variabel quick ratio $(\mathrm{QR})$ pada perusahaan rokok berpengaruh signifikan terhadap harga saham (H1 diterima). Dengan demikian Quick Ratio secara parsial berpengaruh positif terhadap harga saham.

Untuk variabel selanjutnya, nilai uji t untuk variabel Net Profit Margin (NPM) sebesar 7,151 dengan nilai signifikansi 0,000. Nilai signifikansi tersebut 
lebih kecil dari 0,05 sehingga dapat disimpulkan bahwa variabel net profit margin berpengaruh signifikan terhadap harga saham (H2 diterima). Dengan demikian $\mathrm{Net}$ Profit Margin (NPM) pada perusahaan rokok secara parsial berpengaruh positif terhadap harga saham.

Sedangkan variabel ketiga, nilai uji t untuk variabel Total Asset Turnover (TATO) sebesar -0,152 dengan nilai signifikansi 0,880. Nilai signifikansi tersebut lebih besar dari 0,05 sehingga dapat disimpulkan bahwa variabel total assets turnover (TATO) pada perusahaan rokok tidak berpengaruh signifikan terhadap harga saham (H3 ditolak).

Variabel terakhir memiliki nilai uji t untuk variabel Debt to Assets Ratio (DAR) sebesar -2,211 dengan nilai signifikansi 0,032 Nilai signifikansi tersebut lebih kecil dari 0,05 sehingga dapat disimpulkan bahwa variabel debt to assets ratio (DAR) pada perusahaan rokok berpengaruh signifikan terhadap harga saham (H4 diterima). Dengan demikian Debt to Assets Ratio secara parsial berpengaruh positif terhadap harga saham.

Tabel 9.

Uji Kecocokan Model (Uji F)

\begin{tabular}{llllll}
\hline \multicolumn{1}{c}{ Model } & \multicolumn{1}{c}{ Sum of Squares } & \multicolumn{1}{c}{ df } & Mean Square & F & Sig \\
\hline Regression & $3.355 \mathrm{E}+10$ & 4 & 83878368860 & 32.006 & $.000^{\mathrm{b}}$ \\
Residual & $1.127 \mathrm{E}+10$ & 43 & 262071905.5 & & \\
Total & $4.482 \mathrm{E}+10$ & 47 & & & \\
\hline
\end{tabular}

Sumber: Output SPSS, 2021

Goodness of Fit Test atau uji F merupakan salah satu pengujian hipotesis dalam kelayakan model. Suatu hipotesis dapat dikatakan layak yaitu model yang dapat mengestimasi populasi. pengaruh koefisien regresi secara simultan atau secara bersamasama terhadap variabel dependen yaitu harga saham (Gani \& Amalia, 2015).

Uji kecocokan model (Goodness of Fit Test) atau uji $\mathrm{F}$ bertujuan untuk mengetahui variabel-variabel independen secara simultan berpengaruh terhadap variabel dependen. Apabila nilai signifikansi $<0,05$ atau sebesar 5\% atau dengan syarat telah memenuhi $\mathrm{F}$ hitung $>\mathrm{F}$ tabel berarti hipotesis terbukti dan diterima dilakukan secara simultan.

Berdasarkan hasil uji regresi pada Tabel 8. dapat diketahui dan dihasilkan bahwa nilai $\mathrm{F}$ sebesar 32,006 dengan nilai signifikansi yang dihasilkan sebesar 0,000 di mana nilai signifikansi lebih kecil dari 0,05 . Hal ini berarti variabel independen yaitu Quick Ratio, Net Profit Margin, Total Asset Turnover, dan Debt to Assets lebih kecil dari 0,05 atau sebesar 5\% dan hasil ini telah memenuhi uji kecocokan model.

Berdasarkan hasil telah ditunjukkan dengan hasil t hitung $-9,896$ dan nilai signifikan sebesar 0,000 lebih kecil dibanding taraf signifikan yaitu 0,05. Dengan demikian Quick Ratio secara parsial berpengaruh signifikan terhadap Harga Saham (Y). Jika perusahaan melakukan likuidasi dari aktiva lancar sering kali akan berdampak pada kerugian pada suatu perusahaan (Hasdi, 2017). 
Dalam hal ini, teori sinyal memberikan dampak pada perusahaan rokok yang terdaftar di Bursa Efek Indonesia Dengan adanya sinyal yaitu laporan keuangan perusahaan yang disertakan dalam Bursa Efek Indonesia setiap triwulannya, menjadi salah satu alat pertimbahgan dan alat analisis dalam mengambil keputusan untuk menanamkan modal atau dana yang dimiliki oleh baik calon investor dan investor dalam melihat aktiva atau asset likuid perusahaan. Teori sinyal dapat memberikan informasi mengenai kegiatan yang dilakukan oleh perusahaan dalam memberikan informasi yang positif atau bagus mengenai kondisi perusahaan, hal ini berfokus dalam kinerja perusahaan. Dimana quick ratio menghitung kemampuan perusahaan membayar hutang jangka pendek atau kewajiban yang segera jatuh tempo tanpa perusahaan mampu melunasi kewajiban jangka pendek tanpa dikaitkan dengan penjualan persediaan yang dimiliki oleh perusahaan (Sari, 2018). Dalam hal ini maksudkan karena persediaan adalah aset tidak lancar. Jika suatu perusahaan memiliki nilai persediaan yang tinggi, maka perusahaan sulit untuk melakukan proses likuidasi. Quick Ratio digunakan dalam melihat aktiva yang dimiliki oleh perusahaan digunakan secara maksimal dengan tujuan mendapatkan laba sebesar-besarnya untuk melunasi dan menutupi kewajiban yang dimiliki oleh perusahaan (Suryanengsih \& Kharisma, 2020). Dengan semakin meningkatnya nilai Quick Ratio (QR) maka semakin meningkat harga saham, hal ini disebabkan karena investor menggunakan hasil dari QR untuk mengukur kemampuan suatu perusahaan dalam mengoperasionalkan aktiva lancar untuk menutupi utang yang akan jatuh tempo (Alam, 2020).

Quick ratio (QR) adalah salah satu rasio untuk mengukur seberapa besar kemampuan perusahaan dilihat dari seluruh aktiva dan memiliki dampak pada harga saham, dimana kinerja keuangan perusahaan dalam hal membayar atau melunasi kewajiban perusahaan yang segara jatuh tempo dengan kemampuan perusahaan dibayarkan atau dilunasi dengan seluruh aset likuid (setelah dikurangi dengan persediaan) yang dimiliki oleh perusahaan. Dalam hal ini akan mengakibatkan pada harga saham, dimana perusahaan yang mampu membayar hutang-hutangnya mengakibatkan perusahaan akan rugi karena melakukan likuidasi.

Berdasarkan hasil telah ditunjukkan diatas, besarnya nilai yang dihasilkan $\mathrm{t}$ hitung 7,151 dan nilai signifikan sebesar 0,000 lebih kecil dibanding taraf signifikan yaitu 0,05. Dengan demikian Net Profit Margin secara parsial berpengaruh signifikan terhadap Harga Saham (Y).

Teori sinyal sangat berpengaruh terhadap harga saham dalam net profit margin (NPM), dengan bantuan laporan hasil kegiatan produksi dan menghasilkan laba sehingga investor mendapatkan pembagian deviden yakni laporan keuangan memberikan dampak positif bagi harga saham. Dimana semakin meningkat nilai net profit margin (NPM) maka harga saham perusahaan rokok juga semakin meningkat. Teori sinyal memiliki manfaat bagi perusahaan yaitu mendatangkan pemodal atau investor, agar perputaran keuangan yang dilakukan oleh perusahaan dapat berjalan dengan baik sehingga mengasilkan laba yang maksimal. Tingkat penjualan yang tinggi oleh suatu perusahaan akan menghasilkan laba yang meningkat bagi perusahaan (Sari \& Santoso, 2017). Hal ini menjadi salah satu kinerja yang baik dalam perusahaan. Dengan nilai Net Profit Margin, dapat 
menunjukkan bahwa suatu perusahaan mampu meminimalkan biaya-biaya baik biaya operasional maupun biaya administrasi yang digunakan (Damayanti \& Valianti, 2016), dengan hal ini perusahaan mampu melakukan kegiatan produksi dengan efektif dan efisien. Dengan adanya nilai Net Profit Margin yang semakin besar, maka investor menganggap dan mempercayakan untuk menanamkan dananya dengan melihat kemampuan perusahaan dalam menghasilkan laba secara produktif. Semakin besarnya kepercayaan investor, maka saham tersebut banyak dibeli oleh masyarakat dan meningkatkan harga saham (Rahmani, 2020). Semakin besar laba bersih (net profit) yang dihasilkan ole perusahaan akan menjadi salah satu alat ukur yang dilakukan oleh investor dalam menanamkan labanya. Semakin besar laba yang dihasilkan oleh perusahaan setelah dikurangi dengan biaya-biaya operasional, maka akan semakin banyak investor yang menanamkan modalnya (Dewi \& Solihin, 2020).

Dengan demikian, kegiatan produksi yang dilakukan oleh perusahaan rokok memiliki tujuan untuk mendapatkan laba yang terus meningkat, hal ini perusahaan juga perlu memperhatikan dan mempertimbangkan biaya-biaya operasional yang digunakan dan dikeluarkan dalam kegiatan produksi dengan kualitas produk yang baik secara efisien. Hal ini menunjukkan bahwa net profit margin (NPM) dapat berpengaruh terhadap harga saham.

Berdasarkan hasil yang telah ditunjukkan, besarnya nilai t hitung $-0,152$ dengan nilai signifikansi 0,880 . dan nilai signifikan sebesar 0,880 lebih besar dibanding taraf signifikan yaitu 0,05. Dengan demikian Total Asset Turnover secara parsial tidak berpengaruh signifikan terhadap Harga Saham (Y).

Hal ini tidak sesuai dengan teori sinyal, dimana laporan keuangan yang diterbitkan (publish) oleh perusahaan akan memberikan sinyal positif dan akan mempengaruhi investor dalam memilih dan melakukan penanaman modal atau dana. Dengan ditunjukkan adanya penggunaan aktiva dalam kegiatan operasional perusahaan dilakukan secara tidak efektif dan efisien dalam memanfaatkan modal yang dimiliki oleh perusahaan baik modal sendiri maupun modal investor eksternal, dalam hal ini modal yang diinvestasikan tidak menghasilkan revenue yang maksimal (Junaeni, 2017). Aset yang dimiliki oleh perusahaan tidak mampu menghasilkan penjualan dengan tingkat yang tinggi, sehingga perusahaan tidak dapat memaksimalkan seluruh modal maupun aset dalam mendapatkan keuntungan atau laba, hal ini disebabkan karena kinerja keuangan perusahaan dalam menentukan suatu tujuan menghasilkan laba dalam periode tertentu masih belum tercapai dengan adanya biaya produksi maupun biaya administrasi yang melebihi dari yang seharusnya (Nur'aidawati, 2018). Nilai Total Asset Turnover (TATO) yang semakin tinggi disebabkan karena adanya kemampuan perusahaan dalam penggunaan asset perusahaan secara efektif dalam menunjang kegiatan penjualan. Dengan adanya pemanfaatan aktiva yang efektif, maka perusahaan akan memperoleh laba yang meningkat (Ibadhi, 2016). Salah satu alat yang digunakan oleh kreditur maupun investor adalah Total Asset Turnover (TATO), dimana para kreditur dan investor dapat melihat penjualan yang dihasilkan oleh perusahaan apakah dilakukan secara efektif dan efisien dalam penggunaan aktiva perusahaan (Firmansyah \& Masril, 2017). 
Pemanfaatan serta penggunaan aktiva perusahaan menjadi salah satu hal yang dinilai oleh investor baik penggunaan secara efektif serta secara efisien. Dalam hal ini investor tidak melihat apakah perusahaan mampu atau tidak dalam memanfaatkan aktiva untuk meningkatkan penjualan perusahaan, sehingga debt to asset ratio tidak berpengaruh terhadap harga saham

Berdasarkan hasil telah ditunjukkan $\mathrm{t}$ hitung -2,211 dan nilai signifikan sebesar 0,032 lebih kecil dibanding taraf signifikan yaitu 0,05. Dengan demikian Debt to Assets Ratio secara parsial berpengaruh signifikan terhadap Harga Saham (Y).

Dalam hal ini, teori sinyal sangat mempengaruhi harga saham. Dimana nilai debt to asset ratio (DAR) yang dapat dihitung dengan media atau sinyal yang diberikan oleh perusahaan yakni laporam keuangan triwulan dapat mempengaruhi minat dan daya tarik investor dalam memilih perusahaan yang akan ditanamkan modalnya dengan tujuan mendapatkan deviden atau laba dari kegiatan operasional perusahaan. Teori sinyal juga menjadi salah satu daya tarik untuk mendapatkan pemilik modal atau investor yang akan menanamkan modalnya.

Perusahaan yang memiliki kekayaan dalam bentuk aktiva ataupun aset maupun modal usaha yang berasal dari hutang. Hutang yang semakin meningkat untuk memiliki aset pada perusahaan akan mengakibatkan risiko yaitu kerugian yang akan dialami oleh perusahaan (Damayanti \& Valianti, 2016). Hal ini disebabkan karena segala bentuk kekayaan perusahaan maka semakin besar pula bunga atas kewajiban yang harus dibayarkan oleh perusahaan, tetapi semakin meningkat hutang yang dimiliki perusahaan juga mampu meningkatkan kinerja suatu perusahaan dengan adanya tambahan modal untuk operasionalisasi perusahaan dalam menghasilkan keuntungan. Semakin meningkat aktiva yang dimiliki oleh perusahaan dengan dibiayai oleh kewajiban maka akan berdampak pada pengelolaan aktiva pada perusahaan terkait (Widjiarti, 2018). Dengan adanya nilai Debt to Asset Ratio tinggi maka, kemampuan perusahaan dalam membayar hutang dan jika perusahaan menambah hutangnya tetapi tidak menghasilkan keuntungan akan sulit dilakukan karena adanya kepemilikan kewajiban yang harus ditanggung oleh perusahaan semakin bertambah (Murti \& Kharisma, 2020). Debt to Asset Ratio menggambarkan penambahan dan peningkatan hutang perusahaan yang menjadi salah satu penilaian oleh investor. Dengan anggapan, semakin besarnya hutang perusahaan, adanya laba perusahaan yang akan besar di kemudian hari, dan keuntungan yang didapatkan oleh investor juga semakin besar (Wahyuni \& Budiarti, 2020).

Dengan demikian, aktiva perusahaan yang diperoleh dari adanya liabilitas atau hutang akan menambah jumlah hutang perusahaan tersebut. Semakin besar hutang yang dimiliki oleh perusahaan dalam memiliki asset maka perusahaan tidak mampu membayarkan kewajibannya, hal ini disebebkan asset yang dimiliki yaitu berasal dari hutang perusahaan yang semakin meningkat.

\section{SIMPULAN DAN SARAN}

Berdasarkan penelitian yang telah dilakukan variabel-variabel yang telah dipilih oleh peneliti meliputi Quick Ratio (QR), Net Profit Margin (NPM), dan Debt 
to Asset Ratio (DAR) berpengaruh signifikan terhadap harga saham, sedangkan Total Asset Turnover (TATO) tidak berpengaruh terhadap harga saham. Dengan uji kecocokan model variabel-variabel yang telah dipilih dalam penelitian ini yang meliputi Quick Ratio (QR), Net Profit Margin (NPM), Debt to Asset Ratio (DAR) dan Total Asset Turnover (TATO) berpengaruh terhadap harga saham.

Berdasarkan hasil pembahasan dan simpulan diatas, maka saran bagi investor maupun calon investor yang ingin menginvestasikan sahamnya pada suatu perusahaan rokok diharapkan dapat menganalisis kinerja keuangan perusahaan terlebih dahulu sebelum mengambil keputusan untuk menanamkan saham. Investor perlu memperhatikan diantaranya Quick Ratio (QR), Net Profit Margin (NPM), dan Debt to Assets Ratio (DAR) karena berdasarkan penelitian ini rasio-rasio tersebut memiliki pengaruh terhadap baik naik maupun turunnya harga saham.

Dan bagi emiten disarankan untuk lebih meningkatkan kinerja keuangan perusahaan baik secara menyeluruh dalam segala aspek sehingga dapat memperudah calon investor dalam memutuskan pilihan untuk memilih saham mana yang sesuai dengan presepsi calon investor maupun investor yang akan memilih perusahaan untuk ditanamkan modal atau dananya.

\section{REFERENSI}

Adipalguna, S. (2016). Fakultas Ekonomi dan Bisnis Universitas Udayana ( Unud ), Bali , Indonesia Pasar modal di Indonesia saat ini menunjukkan perkembangan bagi perekonomian Indonesia . Perkembangan pesat ini terjadi karena semakin meningkatnya minat masyarakat untuk berinvest. E-Jurnal Manajemen Unud, 5(12), 7638-7668.

Alam, I. K. A. (2020). LAPORAN AKHIR DETERMINAN LAPORAN KEUANGAN TERHADAP HARGA SAHAM PT . UNILEVER INDONESIA , TBK (UNVR) TAHUN Ketua Peneliti: Ilham Kudratul Alam , SE , MM Dilaksanakan Dengan Biaya : Mandiri FAKULTAS EKONOMI DAN BISNIS UNIVERSITAS PERSADA INDONESIA $Y$. A.

Amalya, N. T. (2018). Pengaruh Return on Asset, Return on Equity, Net Profit Margin Dan Debt To Equity Ratio Terhadap Harga Saham. Jurnal SEKURITAS (Saham, Ekonomi, Keuangan Dan Investasi), 1(3), 157-181. https://doi.org/10.32493/skt.v1i3.1096

Astuti, O. D. D. (2018). Pengaruh Return on Asset (ROA), Earning Per Share (EPS), dan Net Profit Margin (NPM) terhadap Harga Saham pada Perusahaan Makanan dan Miniman yang terdaftar di Bursa Efek Indonesia (BEI) Periode 2014-2017. Jurnal Ekonomi Manajemen, 4(2).

Atonius, L., \& Muchamad, S. (2013). Pengaruh Manajemen Modal Kerja dan Rasio Keuangan terhadap Profitabilitas pada Industri Manufaktur yang terdaftar di Bursa Efek Indonesia (BEI) Tahun 2011. DIPENEGORO JOURNAL OF ACCOUNTING, 2, 2. 
Badan Pusat Statistik. (2021). https://www.bps.go.id/

Bursa Efek Indonesia. (2021). https://www.idx.co.id/

Cathelia, N., \& Sampurno, R. D. (2016). Analisis Penaruh ROE, DER, TATO, CAPEX Dan NCCR Terhadap Harga Saham (Studi Kasus pada Perusahaan Manufaktur Sektor Industri Barang Konsumsi yang terdaftar di Bursa Efek Indonesia Periode 2010-2014). Diponegoro Journal of Management, 5(3), 113.

Damayanti, R., \& Valianti, R. M. (2016). Pengaruh DAR, DER, ROA Dan NPM Terhadap Harga Saham Pada Perusahaan Indeks LQ45 Di Bursa Efek Indonesia. Jurnal Media Wahana Ekonomika, 13(01), 16-36.

Daniel. (2015). PENGARUH FAKTOR INTERNAL TERHADAP HARGA SAHAM PADA PERUSAHAAN LQ 45 YANG TERDAFTAR DI BURSA EFEK INDONESIA. 13(3), 1576-1580.

Detik Finance. (2019). Ekspor Rokok dan Cerutu Mengepul Hingga 13 Triliun. https://finance.detik.com/industri/d4470234/ekspor-rokok-dan-cerutumengepul-hinggarp-13-triliun

Dewi, I. K., \& Solihin, D. (2020). Pengaruh Current Ratio Dan Net Profit Margin Terhadap Harga Saham Pada Perusahaan Makanan Dan Minuman Yang Terdaftar Di Bursa Efek Indonesia (Bei) Periode 2015-2018. Jurnal Ilmiah Feasible (JIF), 2(2), 183. https://doi.org/10.32493/fb.v2i2.2020.183-191.6231

Firmansyah, \& Masril. (2017). Pengaruh Pertumbuhan Perusahaan, Total Asset Turnover, Return on Investment, Earning Per Share Terhadap Harga Saham (Studi Perusahaah Manufaktur Di Bei). Ajie, 2(2), 110-121. https://doi.org/10.20885/ajie.vol2.iss2.art3

Gani, I., \& Amalia, S. (2015). Alat Analisis Data: Aplikasi Statistik Untuk Penelitian Bidang Ekonomi dan Sosia. PT. Andi Offset.

Ghozali, I. (2016). Aplikasi Analisis Multivariate dengan Program SPSS. Badan Penerbit Uuniversitas Dipenegoro.

Hasdi, S. (2017). ANALISIS PENGARUH ROI, DTA, QR, TATO, PER PADA HARGA SAHAM PERUSAHAAN BATUBARA DI BEI. Ejournal Stiepancasetia.

Ibadhi, I. (2016). PENGARUH CURRENT RATIO, TOTAL ASSET TURNOVER, DEBT TO EQUITY RATIO, RETURN ON EQUITY DAN EARNING PER SHARE TERHADAP HARGA SAHAM (STUDI PADA PERUSAHAAN OTOMOTIF DI BURSA EFEK INDONESIA). Journal of 
Chemical Information and Modeling, 53(9), 1689-1699.

Junaeni, I. (2017). Pengaruh Economic Value Added, Retrun On Asset, Debt to Equity Ratio dan Total Assets Turnover Terhadap Perusahaan Makanan dan Minuman yang Terdaftar di Bursa Efek Indonesia Tahun 2010-2014. Riset \& Jurnal Akuntansi, 2(1), 32-47.

Kasmir. (2014). Analisis Rasio Keuangan. Journal of Chemical Information and Modeling.

Kholis, M., Astuti, D., \& Febrianti, R. (2016). HUBUNGAN ANTARA PENDAPATAN NASIONAL DAN INVESTASI DI INDONESIA (Suatu Kajian Ekonomi Makro Dengan Model VAR). Jurnal Organisasi Dan Manajemen, 12(1), 65-78. https://doi.org/10.33830/jom.v12i1.48.2016

Murti, R. A., \& Kharisma, F. (2020). Pengaruh Debt To Equity Ratio dan Debt To Asset Ratio Terhadap Harga Saham pada Perusahaan Consumer Goods yang Tercatat di BEI Periode Tahun 2013-2017. Borneo Student Research, EISSN: 2721-5727, 1(3), 2009-2017.

Nur'aidawati, S. (2018). PENGARUH CURRENT RATIO (CR), TOTAL ASSET TURNOVER (TATO), DEBT TO EQUITY RATIO (DER) DAN RETURN ON ASSET (ROA) TERHADAP HARGA SAHAM DAN DAMPAKNYA PADA NILAI PERUSAHAAN ( Studi Kasus pada Sepuluh Bank Terbesar yang terdaftar di Bursa Efek Indonesia Periode. Jurnal SEKURITAS (Saham, Ekonomi, Keuangan Dan Investasi), 1(3), 70-83. https://doi.org/10.32493/skt.v1i3.1091

Pohan, S. (2017). Analisis laporan keuangan untuk mengukur kinerja keuangan pada perusahaan go public di bursa efek Indonesia. Jurnal Manajemen Dan Informatika Komputer Pelita Nusantara, 1(1), 7-11. http:/ejurnal.pelitanusantara.ac.id/index.php/mantik/article/view/219

Purba, N. M. B. (2019). Pengaruh Profitabilitas, Likuiditas, Dan Leverage Terhadap Return Saham Perusahaan Manufaktur Di Bei. Jurnal Akuntansi Keuangan Dan Bisnis, 12(2), 67-76. https://jurnal.pcr.ac.id/index.php/jakb/article/view/2499

Rahmani, N. A. B. (2020). Pengaruh Roa (Return On Asset), Roe (Return On Equity), Npm (Net Profit Margin), Gpm (Gross Profit Margin) Dan EPS (Earning Per Share) Terhadap Harga Saham Dan Pertumbuhan Laba Pada Bank Yang Terdaftar Di Bursa Efek Indonesia Tahun 2014 -2018. HUMAN FALAH: Jurnal Ekonomi Dan Bisnis Islam, 7(1), 6.

Sari, \& Santoso, B. H. (2017). Pengaruh EPS, DER, PBV dan NPM Terhadap Harga Saham Perusahaan Properti. Jurnal Ilmu Dan Riset Manajemen, 6(8), 
$1-15$.

Sari, W. P. (2018). Pengaruh Rasio Keuangan terhadap Harga Saham pada Perusahaan Manufaktur Go Public yang Terdaftar di Bursa Efek Indonesia. Jurnal Ilmiah Syaklandsea, 2(1), 43-52.

Sugiyono. (2018). Metode Penelitian Pendidikan (Pendekatan Kuantitatif, Kualitatif, dan $R \& D)$. Alfabeta.

Suryanengsih, T. D., \& Kharisma, F. (2020). Pengaruh Return On Assets dan Return On Equity Terhadap Harga Saham pada Perusahaan Consumer Goods yang Tercatat di BEI Periode Tahun 2013 -2017. Borneo Student Research, EISSN: 2721-5727, 1(3), 2009-2017.

Tempo Bisnis. (2018). Ekspor Rokok dan Cerutu Tembus 13,22 Triliun. https://bisnis.tempo.co/read/1185947/tahun-2018-ekspor-rokok-dancerututembus-rp-1322-triliun

Untung, B. (2011). Hukum Bisnis Pasar Modal. Andi.

Vivekananda, A., Achsani, N. A., \& Maulana, T. N. A. (2019). Pengaruh Variabel Kinerja Keuangan Perusahaan Dan Makroekonomi Terhadap Harga Saham Batubara: Perbandingan Antara Emiten Lq45 Dan Nonlq45. Jurnal Aplikasi Bisnis Dan Manajemen, 5(3), 347-360. https://doi.org/10.17358/jabm.5.3.347

Wahyuni, H. L., \& Budiarti, A. (2020). PENGARUH LEVERAGE , LIKUIDITAS DAN UKURAN PERUSAHAAN Heni Listia Wahyuni Anindhyta Budiarti Sekolah Tinggi Ilmu Ekonomi Indonesia ( STIESIA).

Widjiarti, K. U. (2018). Pengaruh Debt To Asset Ratio (Dar), Total Asset Turnover ( Tato ), Return On Asset ( Roa), Dan Earning Per Share (Eps) Terhadap Harga Saham Pada Perusahaan Indeks Lq 45 Yang Terdaftar Di Bursa Efek Indonesia Tahun 2013-2017 Effect of Debt To Asset Ra. 2, 1-16. 